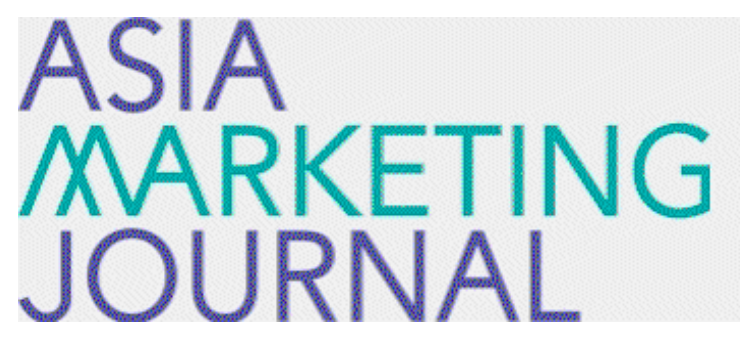

ASIA MARKETING JOURNAL

Volume 6 | Issue 3

Article 6

$10-25-2004$

\title{
트렌드 창출을 톻한 삼성물산 래미안의 브랜드 마케팅전략
}

Jung Ok Jeon

Bong Jin Cho

Myung Sik Lee

Follow this and additional works at: https://amj.kma.re.kr/journal

Part of the Marketing Commons

\section{Recommended Citation}

Jeon, Jung Ok; Cho, Bong Jin; and Lee, Myung Sik (2004) "트렌드 창출을 톻한 삼성물산 래미안의 브랜드 마케팅전략," Asia Marketing Journal: Vol. 6 : Iss. 3 , Article 6.

Available at: https://doi.org/10.53728/2765-6500.1134

This Article is brought to you for free and open access by Asia Marketing Journal. It has been accepted for inclusion in Asia Marketing Journal by an authorized editor of Asia Marketing Journal. 


\title{
트렌드 창출을 통한 삼성물산 래미안의 브랜드 마케팅전략
}

\author{
Making Trend-Based on Brand Marketing Strategy \\ of Samsung Raemian
}

전 중 옥(Jeon, Jung $\mathrm{Ok}) *$

조 봉 진(Cho, Bong Jin)**

이 명 식(Lee, Myung Sik)***

국내 아파트 시장에서 래미안을 통해 브랜드 마케팅을 본격적으로 도입한 삼성물산 건설부문은 고 객의 추구가치를 마케팅믹스전략에 철저히 반영하는 한편 새로운 브랜드 마케팅전략의 트렌드를 창 출하고 주도한 결과, 업계 최고의 파워브랜드 구축과 함께 괄목할 만한 경영성과를 단기간에 이룰 수 있었다. 본 사례는 삼성물산 건설부문이 래미안을 최고의 파워 브랜드로 만들기 위해 기울인 체계적 노력을 브랜드 마케팅전략을 중심으로 소개하고, 주요 성공요인이 무엇인지 알아본 후, 시사점과 함 께 향후 래미안의 전략적 과제를 제시하고 있다.

핵심개념: 삼성 래미안, 브랜드 마케팅, 브랜드 자산, 주택건설

\section{I. 서 론}

1998년에 접어들면서 아파트 신규분양시장은 부동산 가격 폭락, 소비자의 아파트 품질에 대 한 비차별적 인식 및 기업간 경쟁 심화 등으로 인해 미분양이 속출하고 주요 건설업체들이 잇 달아 도산하는 등 아파트 건설업이 위기의 상 황에 놓이게 되었다. 이에 구매력 제고와 차별 화된 구매패턴을 충족시켜 줄 새로운 마케팅이
필요하게 되었다. 이러한 상황에서 삼성물산 건 설부문에서는 후발주자의 약점을 극복하고 경 쟁적 우위를 확보하기 위해, 획기적이고 차별화 된 상품 및 기술을 기반으로 회사명 일색이었 던 아파트 시장에 고객 인식상 차별적 가치를 지닌 강력한 아파트 브랜드가 필요하다는 인식 하에 래미안(來美安)을 2000년에 출시하게 되 었다.

아파트 시장에서 래미안을 통해 브랜드 마케

* 부경대학교 경영학부 교수(jojeon@pknu.ac.kr).

** 계명대학교 경영학과 교수(bjcho@kmu.ac.kr).

*** 상명대학교 경영학부 교수(mslee@smu.ac.kr). 
팅을 본격적으로 도입한 삼성물산은 목표고객 인 주부들이 추구하는 가치를 마케팅믹스전략 에 철저히 반영하여 래미안을 통해 자부심을 성취하고자 하는 데에 초점을 두었다. 특히 엄 격한 브랜드관리와 통합적 마케팅 커뮤니케이 션에 주력하여 브랜드의 개념조차 생소한 건설 업계에서 새로운 브랜드 마케팅전략의 트렌드 를 창출하고 주도한 결과, 브랜드 파워 및 선호 도 1 위라는 리딩브랜드 입지 구축과 함께 수주, 시공권, 매출 측면의 성과 지표 등에 있어서도 괄목할 만한 경영성과를 단기간에 이룰 수 있 었다.

본 사례는 삼성물산 건설부문이 래미안을 주 택업계 최고의 파워 브랜드로 만들기 위해 어 떠한 노력을 기울여왔는지를 브랜드 마케팅전 략을 중심으로 살펴보고, 래미안의 성공요인 분 석을 통해 동종 및 타업계에의 전략적 시사점 을 발견하는 한편, 향후 업계와 시장선도를 위 한 래미안의 전략적 과제를 검토하는 데에 그 목적이 있다.

\section{ㅍ. 래미안 브랜드의 탄생과정}

\section{1 주택 상품의 특성}

주택 상품의 특성에 대해 첫째로 주택은 복 합체라는 점을 꼽을 수 있다. 이는 주택이 여러 가지 요소들을 여타 산업에서 공급받아 생산하 는 서비스의 복합체로 투입재에 따라 이질적인 효용을 나타내기 때문이다. 둘째, 주택은 주변 에 각종 공공시설, 구매·편익시설, 의료시설, 안전보호시설 등이 필요한 종합상품이다. 셋째,
주택은 내구성 및 위치의 고정성을 가진 산업 이다. 즉 주택은 내구연한이 긴 재화로 장기간 에 걸쳐 효용을 창출하며 위치가 고정되어 있 어 거주 이동으로 소비를 조절하게 된다. 넷 째, 주택은 고가성을 가진다. 주택은 값이 비 싸 구입하는데 많은 돈이 소요되며 금융 지원 이 뒷받침되어야 생산이 촉진되고 구매수요가 창출된다. 다섯째, 주택은 양면성을 가진다. 즉 소비재인 동시에 투자재로서 주택건설 및 거 래는 경기에 민감하고 거시경제정책에 민감하 다(대한주택건설협회 홈페이지). 이와 같이 주 택 상품의 다중적 특성으로 인해 주택업계의 마케팅전략 운용 또한 높은 주의도를 요구하 고 있다.

\section{2 래미안 브랜드의 탄생배경}

래미안의 탄생을 앞둔 1998년의 아파트 신규 분양시장은 $\mathrm{IMF}$ 금융위기로 인한 급격한 기 업환경의 악화와 함께 부동산 가격 폭락으로 미분양 사태가 속출하는 최악의 시기라 할 수 있다. 불황의 전형이라 할 수 있는 기업 도산 의 도미노는 건설업계에도 몰아쳐서 주요 건 설업체들의 연쇄부도로 이어지는 붕괴 직전의 위기 상황이었다. 이러한 상황 속에서 고금리 의 금융시장 매력성으로 인해 시중의 자금이 금융 및 주식에 집중되는 반면 건설업체의 수 익성과 부채비율 등은 갈수록 악화되는 양상 을 보이게 된다. 뿐만 아니라 미분양으로 인한 매출 부진을 타개하기 위해 업체들의 출혈성 가격경쟁이 나타나게 되고, 이는 결국 건설업 체의 수익성 악화라는 악순환의 구조에 놓이 게 되었다. 


\section{삼성물산의 기업 개요}

사업 현황

- 창립: 1938년

- $\mathrm{CEO}$ : 이상대(건설부문 대표이사 사장) 정우택(상사부문 대표이사 사장)

- 임직원 수: 약 4.240명 (2004년 4월 현재: 해외 현지인력 별도)

- 매출: 9 조 360 억원(2003년도)

* 2003년부터 매출액 산정에 대한 변경된 희계기준(대형매출 제외) 적용

(참고: 2002년의 매출: 36 조 9168 억원)

- 총자산: 8 조 7500 억원(2003년도)

- 순이익: 819 억원(2003년도)

삼성물산은 1938년 창업 이래 무역을 통해 한국 산업의 고도화와 세계화를 선도해 왔으며. 1975년 정부 로부터 한국 종합상사 1호로 지정 받은 이후 본격적인 해외 영업을 확대해 한국의 대외 무역을 선도적으 로 이끌어 온 국내 최정상급 트레이더이다.

삼성물산은 무역업에 한정된 사업 영역을 벗어나 70 년대에 의류업을 시작했으며 1995년엔 삼성건설과 퉁합하였다. 1997년에 유통업에 신규 진출했고 1999년에는 의류부문이 제일모직으로 이관되었다. 이로써 현재 삼성물산의 사업 영역은 크게 상사. 건설로 나뉘며 상사부문 내에 유통 본부가 있고 건설부문은 2002년 1월을 기점으로 1998 년 분리돼⿺던 주택부문과 다시 퉁합하였다.

삼성물산의 건설 부문인 삼성건설은 건축, 토목, 플랜트, 개발, 주택 사업을 수행하며 지상 92 층, 높이 $452 \mathrm{~m}$ 로 세계 최고층인 말레이시아 KLCC페트로나스 빌딩, 부산 가덕도 신항만, 인천 국제 공항 공사를 비롯해 울진 원전 건설, 환경, 에너지 시설에 이르기까지 다양한 분야에서 그 사업을 하고 있다.

특히 차별화, 고급화된 최고 품질의 삼성아파트 '래미안'올 공급함으로써 재건축. 재개발. 조합주택 등 수주 사업에서 국내 최고의 시장 점유율을 자랑하고 있으며 7년 연속 국가고객만족도 1위로 선정되었다.

\section{〈표 2-1〉 삼성뭅산 사업 현항}

\begin{tabular}{|c|c|c|}
\hline \multirow[t]{5}{*}{ 상사부문 } & 정보통신 & 컴퓨터, 통신기기, 가전 \\
\hline & 기계 - 풀랜트 & 수송장비, 산업장비, 일반기계, 풀랜트, 기계설비 \\
\hline & 철강-금속 & 열연 - 냉연강판, 도금강판, 스텐래스, 비철금속, 귀금속 \\
\hline & 화학 & $\begin{array}{l}\text { 석유화학제픔, 합성수지제품, 유기화학제픔, 무기화학제품, 정밀화학제품, } \\
\text { 고무원료 및 제품, 종이원료 및 제품 }\end{array}$ \\
\hline & 자원 & 구리, 석유 및 가스, 석탄, 식량 \\
\hline 건설부문 & \multicolumn{2}{|c|}{$\begin{array}{l}\text { 건축, 토목. 플랜트 } \mathrm{SOC} \text { 사업 } \\
\text { 주백 신축 - 판매사업 } \\
\text { (자체 신축 · 분양사업/일반도굽사업 /재개발 - 재 건축사업) }\end{array}$} \\
\hline 유통본부 & \multicolumn{2}{|c|}{ 삼성풀라자 분당점, 삼성인터넷 쇼평믈, 유투존 운영 } \\
\hline \multirow[t]{2}{*}{ 미래전랴사업 } & 상사 & 븍합서비스 삼국 간 거래 강화, 중국시장본격 진출, 브랜드사업 강화 \\
\hline & 건설 & $\begin{array}{l}\text { 5대 상픔 및 } 3 \text { 개미래 수종 사업육성. 엔지니어링+CM기능강화, 부동산종합 } \\
\text { 서비스체제 구축 }\end{array}$ \\
\hline
\end{tabular}


이에 정부는 부동산 시장 활성화를 통한 경 기 부양을 위해 그동안 제한해 오던 분양가 상 한선을 폐지하게 되었으며, 이는 곧바로 건설업 체의 새로운 기회로 작용하게 되었다. 과거 국 내의 경우 아파트 평수에 따라 분양가가 제한 되어 있어 제한된 가격에 따라 아파트를 건설 하기 위해 차별성이 부각되지 못한 아파트를 고객에게 공급하고 있었다. 즉 정해진 가격에 따른 공급자 위주의 설계 및 분양으로 입주자 인 고객에 대한 배려나 전략이 크게 부각되지 못한 상황이었다.

분양가 상한선의 폐지는 건설업체에게 있어 제품 품질의 동등화를 넘어 차별화된 상품을 제공할 수 있는 기회가 되는 한편, 소비자에게 는 차별화된 주거 욕구와 가치를 지닌 상품을 선택하고자 하는 인식변화의 계기가 되었다. 즉 아파트 시장이 공급자 위주의 시장에서 수요자 위주의 시장으로 변화하기 시작한 것이다. 이에 따라 아파트 상품의 개발에서부터 분양에 이르 기까지 입주자의 편리함이나 요구를 적극 반영 함과 아울러, 차별화된 고객의 구매욕구를 충족 시켜 줄 새로운 마케팅이 필요하게 되었다.

주택업의 특성상 획기적으로 차별화된 상품 및 기술의 개발이 현실적으로 곤란한 점을 가 지고 있으나 삼성건설은 고객인식상의 차별적 가치를 지닌 상품과 기술을 기반으로 과거 회 사명 일색이었던 아파트에 별도의 제품 브랜드 를 적용하기로 하였다. 즉 삼성건설이 후발주자 의 약점을 극복하고 경쟁에서 승리하기 위해서 는 고객인식상 차별적 가치를 지닌 강력한 브 랜드의 존재가 필요하다고 판단하였다. 이에 따 라 삼성건설은 '한국형아파트'에 이어 '사이버아 파트'를 선보이고 98년 5월 5개 지역 동시분양
을 실시하여 성공적 분양과 함께 주목을 받았 다. '사이버아파트'는 당시 분양아파트의 표준이 되었으며, 정보통신부가 '초고속정보통신아파트' 라는 정부 인증제도를 만드는 계기가 되기도 했다. 하지만 '한국형아파트', '사이버아파트'는 아파트의 핵심 주거가치를 반영하지 못하고 있 으며 '삼성이 만든 아파트'라는 의미 이상의 차 별화된 이미지를 전달하기에는 역부족이었다. 또한 경쟁 업체들이 유사상품을 출시함으로써 삼성건설로서는 절대적인 우위를 만들어 내기 위한 삼성건설 고유의 새로운 브랜드를 출시하 기로 결정하였고, 이렇게 해서 2000년 3월 탄생 한 것이 바로 '래미안'이다.

\section{3 래미안 브랜드의 탄생}

미래를 내다보는 공간, 아름다움을 담는 공간, 편안하고 안락한 공간. 이것은 모든 사람들이 이상형으로 삼고 있는 '집'이다. 그런 집을 삼성 건설은 “來/美/安”이라고 부르기로 결정했다. 즉 단순히 사고 파는 상품으로서의 아파트가 아니라 생활을 담고 삶을 계획하는 삶의 공간 이자 살고 싶은 집의 대명사가 탄생한 것이다. 현대, 대우 등 기업명이 아파트 이름을 대신하 던 시기에 삼성아파트가 래미안이라는 새 이름 으로 얼굴을 드러낸 것은 2000년 3월이었다. 삼 성아파트를 대표할 신규브랜드를 만들 것을 결 정한 뒤 무려 1 년간의 준비기간을 거친 후였다. 앞서의 탄생배경에서도 언급된 것처럼 분양가 자율화가 가져다 준 의미는 충분한 개성을 살 린 아파트를 짓는 것이 가능해졌다는 것이고, 동시에 그만큼 직접 그 집에서 살게 될 고객의 선택이 한층 중요해졌다는 것을 의미한다. 이에 
따라 잠재고객들에게 자사 아파트만의 장점을 홍보할 수 있는 보다 적극적인 수단인 브랜드 의 필요성이 대두되었다.

이같은 시장의 경쟁국면 변화에 따라 첫 시 도된 작품이 98년 한국형, 99년 사이버 아파트 였다. 베란다의 창호무늬를 내세운 98년의 '한 국형아파트', 인터넷의 폭발적인 증가를 감안한 ‘사이버아파트'도 고객들에게 좋은 인상을 주었 지만, 그것만으로는 부족했다. 한편 99년도 삼 성중공업에서 내세운 브랜드인 '쉐르빌'의 폭발 적인 인기는 래미안이 탄생하는 데 있어 결정 적인 계기를 제공하게 되었다.

\subsection{1 래미안 브랜드 도출 과정}

고객인식상의 차별적 가치를 지닌 강력한 브 랜드의 필요성이 제기됨에 따라 삼성건설은 브 랜드 도출을 위한 일련의 과정을 체계적이면서
도 엄정히 그 단계를 밟아 나갔다. 즉 (1)기업 내부의 전략 및 자원분석을 통해 기업의 비전 과 미션을 재확인하고 미래사업의 전개방안을 수립하고, (2)경쟁구조 및 경쟁관계 분석을 통 해 향후 주택시장의 트렌드를 분석하고 경쟁사 의 포지셔닝 및 브랜드 전략을 파악하는 한편, (3)아파트에 대한 소비자 욕구 분석을 통해 고 객의 미래 주거가치를 확인하였다. 이를 통해 새로운 브랜드의 아이덴티티를 구축하기 위한 신규 브랜드의 포지셔닝과 브랜드의 컨셉을 정 립하고 이에 따라 브랜드 네이밍의 방안을 개 발하였다(<그림 2-1> 참고).

삼성건설은 신규 브랜드가 추구하는 브랜드 비전으로 "끓임없는 도전과 개척정신으로 고 객에게 최적화된 가치를 제공하는 세계적인 주거생활 브랜드"라 규정지었다. 이는 곧 지속 적인 $\mathrm{R} \& \mathrm{D}$ 를 추구함과 아울러 새로운 사업기 회를 모색하고, 개별고객 각자가 중요시하는

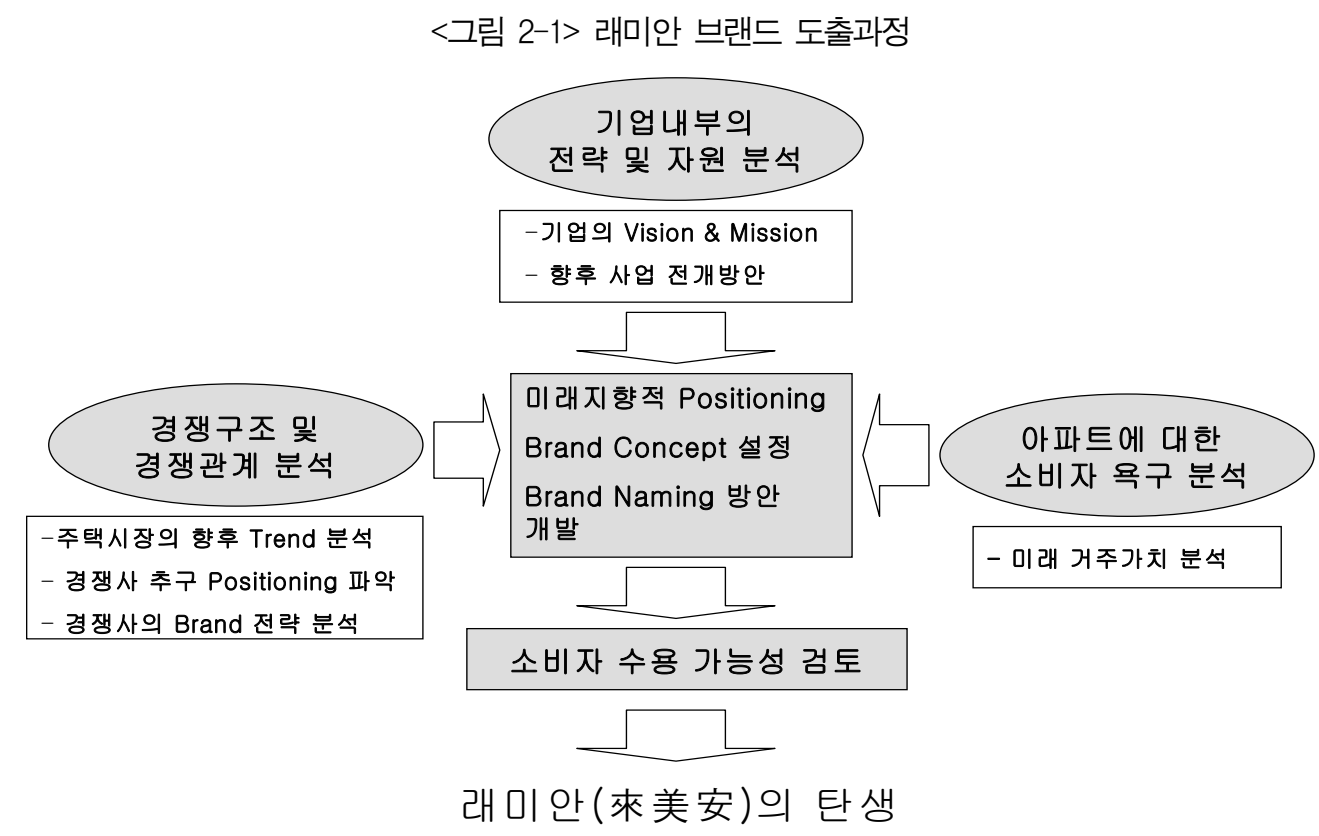

트렌드 창출을 통한 삼성물산 래미안의 브랜드 마케팅전략 
생활편의, 경제적 혜택 등과 같은 다양한 가치 (customized value)를 추구하며, 주거생활에 관 련된 모든 분야를 하나의 언어로 표현할 수 있 는 대표브랜드의 지향을 의미한다고 볼 수 있다.

\subsection{2 브랜드 네이밍 기본전략}

삼성건설 아파트를 대표하는 브랜드의 네이 밍을 위해 '다양한 시장환경 변화에 대응하는 강력한 브랜드 구축을 통해 21 세기 주거문화를 선도하는 기업의 위상 구축'이라는 미션아래 브 랜드 개발의 기본원칙이 제시되었다. 첫째, '주 거환경 - 성능의 향상을 바탕으로 한 주거문화 창달'이라는 회사 및 상품의 중장기적 비전과 전략이 함축적으로 내포될 것. 둘째, 삼성아파 트의 명확한 브랜드 컨셉 설정이 용이할 것. 셋 째, 주거가치 중 핵심가치의 선점 및 기존 자산 및 이미지와의 연계가 가능할 것 등을 지침으 로 삼았다. 또한 브랜드명은 상품의 성격·기능 과의 부합성, 품질 신뢰성과 참신성, 발음 및 기억용이성, 품격과 차별성 등이 용이해야 함을 원칙으로 정하였다. 또한 그룹과 회사가 가지고 있는 장점과 좋은 이미지의 적극 활용을 권장 하였다.

한편 브랜드 네이밍의 기본 컨셉으로 주거관 련의 소비자 욕구 변화 즉 소비자의 추구 지향 점에 기초하여 생활공간으로서의 가치추구 위 에 미래 주거가치 예측을 통한 주거핵심가치의 선점에 두었다. 이를 위해 환경친화, 첨단기능, 건강중시, 생활서비스, 커뮤니티, 가족중시로 구 체화되는 핵심가치에 삼성그룹과 삼성아파트 이미지가 주는 후광효과를 감안하여 브랜드명 을 완성하고자 하였다.
구체적인 브랜드 네이밍 전개방안으로 단일 브랜드 네이밍을 이용한 단순 의미전달, 사업별 /등급(grade)별 분류, 프로젝트별 장소/형태/기 능/규모를 고려한 네이밍 등 각 방안별 브랜드 네이밍의 장단점을 비교한 결과 단일 브랜드 네이밍을 취하기로 하였다.

\subsection{3 브랜드명의 선정}

사내공모 및 네이밍 전문회사의 도움으로 최 종대안에 올라온 것은 LIVEX, DAUS, e-Heim 등 대부분이 외국어였다. 유일한 한자명이었던 來美安은 두 번째로 올라온 제안 중에서도 가 장 낮은 지지를 받았다. 당시의 트렌드에 비추 어 한자는 적절치 않아 보였고, 르 발음이 초성 인 경우는 낮설 뿐 아니라 발음하기 어려워 고 객들에게 거부감을 일으킬 염려도 있었다. 또한 '來'자가 '소'자와 비슷해서 '졸미안'으로 읽힐 가능성이나, '네, 미안(합니다)'으로 읽힐 위험 성을 지적하는 우려의 목소리도 있었다. 그러나 트렌드를 주도하는 $\mathrm{CEO}$ 의 강력한 지지가 브랜 드명 “래미안"에 큰 힘을 실어주었다.

의도한 것은 아니었지만 '나의 것들', '나의 가까 운 사람들'이라는 의미의 '래미엔느(Lesmiennes)' 와 발음이 비슷하다는 것이 장점으로 부각되면 서 "래미안"의 수용성이 높아질 수 있었다. 그 와 더불어 미래지향적이며(來) 아름답고(美) 안전한(安) 아파트라는 브랜드명의 상징성은 삼성아파트가 지향하고 있는 제품 특성과 일치 하여, 브랜드가 시장에 성공적으로 안착하는데 있어 가장 적절한 이름이라고 확신하게 되었다. 


\section{III. 래미안의 브랜드 마케팅전략}

\section{1 브랜드 런칭기(2000년 - 2001년)}

국내 최초로 본격적인 아파트 브랜드의 시대 를 연 삼성건설은 래미안을 주택업계 최고의 파워브랜드로 만들기 위해 도입기 전략에서부 터 브랜드 자산 구축을 위한 다양하고 체계적 인 마케팅 노력을 기울였다.

브랜드 아이덴티티(brand identity)란 기업이 브랜드에 대해 고객들의 마음속에 심어주고 싶 은 바람직한 연상들(brand associations)로 정의 될 수 있다. 따라서 브랜드 아이덴티티를 수립 한다는 것은 고객들에게 브랜드에 대해 궁극적 으로 어떤 이미지를 각인시킬 것인가를 결정하 는 것, 즉 브랜드에 대한 장기적인 비전의 수립 을 의미한다. 이를 위해 래미안은 '고객 각자가 중요시하는 가치'를 제공하며, 고객은 래미안을 통해 '자부심'을 성취하는 것에 브랜드 아이덴 티티를 두고 진행되었다.

래미안의 목표고객으로 실제 사용자는 가족 이지만 가족 구성원 중 실질적인 의사결정자는 주부라는 관점에서 30-40대의 지적이고 세련된 주부를 선정하였다. 또한 브랜드 개성을 위해 30-40대의 도시인, 중상층, 세련된, 깔끔한, 단 정한, 꼼꼼한, 약속을 지키는, 앞서 나가는 등의 키워드가 제시되었다.

그러나 초기 런칭시(런칭후 5개월)의 마케팅 전략은 익숙치 못한 래미안의 발음 만큼이나 시행착오를 겪었다. 우선 조기 런칭을 위해 전 달자 중심의 과욕을 부렸다는 점이다. 즉 고객 에게 상품 컨셉 등 너무 많은 것을 한꺼번에 보 여주려 하였으며, 상품적 가치표현에 집착하여
설명이 길어져 고객에게 너무 무겁게 전달되었 다 할 수 있다. 둘째, 고객에게 어렵게 전달되었 다는 점이다. 즉 브랜드의 명확한 고지보다 개 념의 설명을 먼저 하고자 하거나, 음운상 초기 전달 상의 혼동, 커뮤니케이션에 있어 브랜드와 상품과 동떨어진 슬로건-참을 수 없는 기쁨-등 이 그것이다. 이 외에도 기존 브랜드와의 충돌, 전략 집행에 있어서의 시간 제약 등이 있었으나 이러한 시행착오는 어쩌면 시장 도입기에 당면 하게 되는 공통적인 산고일지도 모른다.

이상의 엄정한 현상분석을 토대로 일부의 전 략 수정과 함께 리런칭 전략을 수립하고 본격 적인 마케팅 전략을 집행하게 되었다. 우선 목 표고객으로 30-40대 초반의 여성과 함께 자녀 층으로서 컴퓨터에 익숙한 어린이를 포함하여 설정하였으며, 여성과 어린이를 위한 아파트에 포지셔닝하였다. 이는 삼성이 섬세하고 세련된 여성의 이미지이며, 래미안이 세련된 도시여성 의 이미지를 지향한다는 점에 기초하였다. 또한 어린이는 미래의 고객이자 의사결정의 중요한 기준으로서 주거공간은 어른 위주로 구성된 반 면, 주택의 선택기준 중 교육여건이 최우선시되 는 이중적 구조를 가지고 있다. 또한 여성은 전 통적으로 가장 영향력있는 구전홍보 등의 홍보 매개체로서, 어린이는 가장 정직한 정보 전달자 로서 그 역할이 기대되었다.

상품개발의 방향성에 있어 우선 상품과 브랜 드를 분리시켜 래미안이 곧 삼성아파트임을 고 지하고, 상품 중심의 브랜드에서 고객중심의 브 랜드로 속성을 전환시켜 개별 특성을 설명하는 것보다 공통지향점인 고객에게 포커스를 맞추 었다. 브랜드 자산 구축을 위한 마케팅믹스 전 략을 구체적으로 살펴보면 다음과 같다. 


\subsection{1 제품전략}

첫째, 첨단, 튼튼함, 안전, 에너지 절약, 저소 음, 청정환기, 환경친화 등의 컨셉이 포함될 수 있는 상품개발에 주력하였다.

둘째, 고객지향적 상품개발을 위해 고객정보 의 수집에 만전을 기하였다. 그 일환으로 분양 전 소비자 선호도와 희망 마감재에 대한 시장 조사, 모델하우스 방문 고객조사 등 사전조사에 서부터 입주후 만족도 조사에 이르기까지 상품 에 대한 고객 욕구 파악과 피드백을 철저히 분 석하여 상품개발에 반영하고자 하였다. 또한 21 세기 위원회, 첨단 주택개발 위원회, 상품개발 위원회, 주부 주택컨설팅 시스템 등을 도입하여 그 결과를 상품개발에 적극 반영하였다.

셋째, 철저한 품질 보증을 위해 모델 하우스 오픈에서 입주후 6 개월 시점까지 4단계에 걸친 품질점검을 원칙으로 삼는 한편, 좋은 집 만들 기 행사와 입주자 사전 점검제 및 전문가 평가 등 품질의 다면평가를 제도화하여 실시하였다.

넷째, $\mathrm{A} / \mathrm{S}$ 체제 강화를 위해 순회서비스반과 고객지원센터를 설치 운영하였다.

다섯째, 건설업계 최초로 본격적인 6시그마 경영을 시작하였고 이와 더불어 적극적인 품질 향상을 위한 $\mathrm{CZ}$ 운동(customer satisfaction \& zero defect: 고객만족 및 무결점)을 추진하였다.

\subsection{2 가격전략}

첫째, 신규분양 아파트의 가격전략에 있어 시 장정보에 기초한 가격책정을 기조로 하여 프리 미엄급 아파트 상품에 적합한 가격책정을 하는 한편, 프로젝트별 특성을 감안한 상황가격제를
병행하였다.

둘째, 분양가 차등지침의 적용을 강화하기 위 해 다단계 가격산정 방식을 채택하는 한편 가 격에 대한 태도조사를 정례화하여 수요예측에 대한 과학적인 분석을 실시하였다.

\subsection{3 유통전략}

아파트 분양의 특성상 고객과의 접점이자 실 질적 구매시장이라 할 수 있는 주택문화관을상 설운영하였다. 즉 주택문화관에서 다양한 문화 프로그램의 운영을 통해 문화마케팅의 장으로 삼고 래미안의 주택문화를 실제 체험할 수 있 는 공간을 제공하였다. 또한 다양한 정보의 발 신지 역할을 위해 제휴업체 전문상담역을 배치 하여 오프라인 주택정보를 제공하고 리모델링, 전자제품, 인테리어 소품, 주택 캐릭터 상품을 전시하는 등의 활동을 하였다.

\subsection{4 촉진전략}

래미안의 조기 인지도 강화와 브랜드 자산 구축을 위해 TV 광고를 주매체로 하되 다양한 매체간의 효율성을 극대화하기 위해 통합적 마 케팅 커뮤니케이션 전략을 구사하였다. 우선 방 송과 인쇄광고에 있어 주택업계 최초로 여성과 주부를 이해하기 시작한 아파트 브랜드로서 이 들의 입장에서 아파트를 바라보는 관점을 일관 되면서 입체적으로 표현해 세련되면서도 살아 있는 이미지를 구축할 수 있었다. 한편 TV 광 고의 집행에 있어 런칭 초기의 광고가 빅모델 과 함께 이성적 소구와 감성적 소구를 동시에 추구하고자 함에 비해, 리런칭 이후에는 주요 
속성과 함께 브랜드 아이덴티티를 나타내는 메 시지를 품격있게 전달하고자 하였다.

한편, 고객관리의 강화를 위해 $\mathrm{CRM}$ 체제를 구축하고 홈페이지를 통한 고객관리와 함께 모 의청약과 가구경매 등 다양한 온라인 이벤트를 실시하여 고객 관심을 증대시켰다. 또한 다양한 고객 이벤트를 실시하였는데 이에는 인터넷 무 료 교육, 래미안 아카데미(서양미술사 과정) 운 영, 래미안 재즈 페스티발, 래미안 그린 수비대, 회원지 발간 등 다채로운 이벤트가 있다.

이러한 도입기 마케팅 전략의 결과, 런칭 첫 해부터 국가고객만족도(NCSI) 및 브랜드 파워 1 위에 올라 리딩 브랜드의 목표를 달성하고, 사 상 최고의 청약률을 기록하는 한편, 첨단/신뢰/ 고급감/투자가치 등 브랜드의 긍정적 이미지 제 고라는 성과가 있었다. 그러나 래미안 만의 강 력한 고유연상이 부재하며, 상품기획 및 커뮤니 케이션의 일관성이 부족하고, 브랜드 체계가 채 정립되지 않는 등의 문제점을 안고 있는 것으로 나타났다. 이에 파워 브랜드로의 도약을 위한 브랜드 아이덴티티의 재정립이 필요한 것으로
나타나 재도약기의 최대 과제로 등장하였다.

3.2 브랜드 재도약기(2002년 - 현재)

2002년에 이르러 삼성건설은 도입기 런칭전 략의 기본 틀을 유지하면서 런칭 기간동안 드 러났던 문제점의 개선을 위해 브랜드 아이덴티 티를 재정립하고 브랜드 자산 창출의 극대화를 위한 마케팅믹스 전략의 보완에 주력하였다.

브랜드 아이덴티티의 재정립 방안으로 이미 구축된 이미지 자산을 토대로 차별화되고, 생명 력을 지니며, 표현이 용이한 단일 개념(single concept)을 도출하고자 하였다. 그 결과 2002년 2월 래미안의 브랜드 아이덴티티를 구축하였다.

우선 브랜드 아이덴티티의 원천이자 브랜드 가 고객에게 중장기적으로 전달하고자 하는 철 학적 가치체계인 브랜드 플랫폼을 정립하였다. 브랜드 플랫폼의 구성요소는 아래와 같이 구체 화되었다.

<그림 3-1> 래미안의 브랜드 아이덴티티 체계

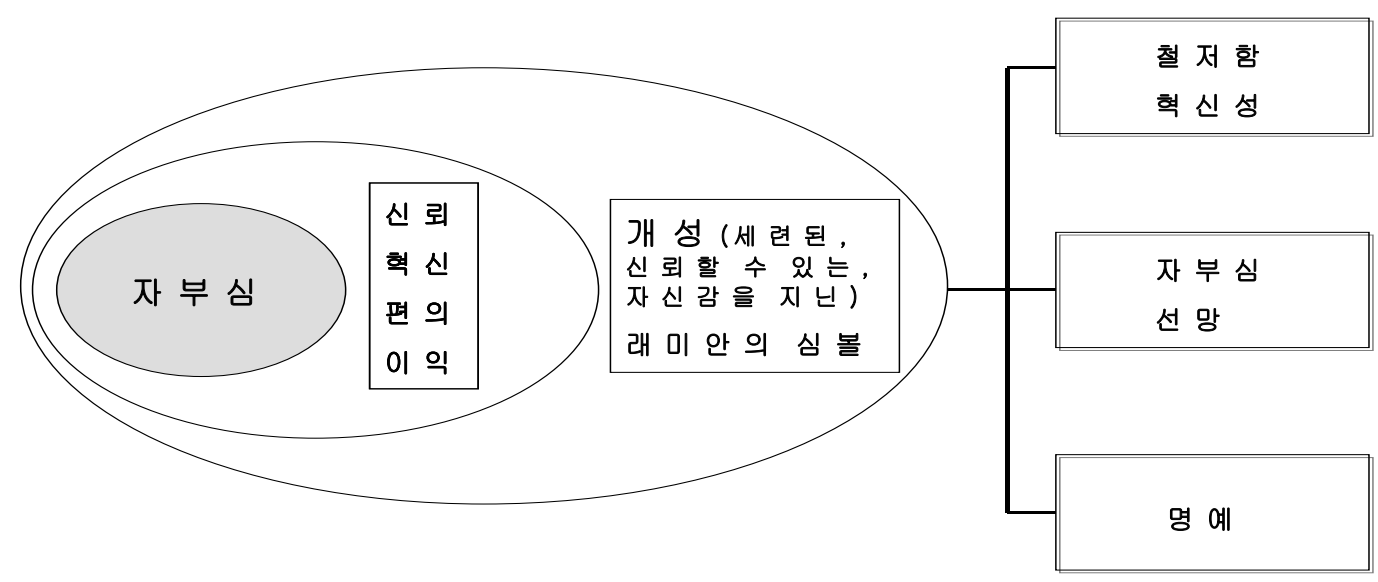

트렌드 창출을 통한 삼성물산 래미안의 브랜드 마케팅전략 131 
- 브랜드 핵심역량: 고객에게 다양한 혜택을 제 공할 수 있는 가치 인프라의 구축 능력

· 포지셔닝: 자부심이 다른 아파트

- 개성: 세련된, 신뢰할 수 있는, 자신감을 지닌

- 미션: 새롭고 독특한 가치의 창출, 진실된 가 치의 체험기회 제공, 새로운 사업영역으로의 확장

- 비전: 끊임없는 도전과 개척정신으로 고객에게 최적화된 가치를 제공하는 세계적인 주거문화 브랜드

이에 따라 기업(브랜드)이 고객의 마음 속에 심어주기를 원하는 바람직한 연상들 또는 이미 지라 할 수 있는 브랜드 아이덴티티는 소비자 들로 하여금 일관되고 강력한 이미지 형성이 가능하도록 체계화하였다. 브랜드 아이덴티티의 구성요소는 다음과 같이 구체화되었다.

· 브랜드 에센스: 자부심

· 핵심 아이덴티티: 신뢰, 혁신, 편의, 이익

· 확장 아이덴티티: 개성, 심볼

이상의 아이덴티티 체계의 재구축에 따라 2002년 7월 개별 브랜드 체계의 확립이 이루어 졌다. 우선 제품 특성상 자소 혼란스러운 제품 카테고리별 브랜드 적용의 기준 정리를 통해 브랜드 관리의 효율성을 제고하고자 하였다. 이 에 따라 아파트에는 '래미안' 만을 적용시키는 것을 통해 브랜드 파워의 향상을 시도하였다.

이러한 브랜드 체계 정립은 ‘래미안’이 단순한 상표가 아니라 자신만의 고유한 철학을 지닌 '브랜드'로서 자리매김함을 의미하며, 이는 곧 '래미안'이 장기적으로 꾸준히 성장할 수 있는 기반을 확보하였다는 점에서 매우 중요한 의미
를 지닌다.

브랜드 아이덴티티를 '자부심'으로 설정한 래 미안은 고객의 추구가치와 브랜드 자산의 극대 화를 위해 브랜드 자체가 마케팅 프로그램에 효과적으로 통합될 있도록 최적의 마케팅믹스 전략을 설계하고 실현하였다.

제품전략에 있어 런칭기의 기본 전략을 토대 로 하되 보다 브랜드 이미지에 적합한 상품컨 셉을 개발하는 데에 주력하였다. 이를 위해 주 거편의의 극대화와 세련된 품격의 이미지를 전 달할 수 있는 상품컨셉 개발을 위해 다양한 조 사를 실시하는 한편, 꿈과 스토리가 담긴 공간 을 창출하기 위해 적극적으로 고객 욕구를 분 석하고 수용하였다. 또한 입지 선별을 통한 상 품가치의 개선에 주력하여 부지 선정시 래미안 $\mathrm{CBO}$ (chief brand manager)가 직접 현장을 방 문하여 래미안 컨셉과의 적합도 분석을 통해 입지를 선정하였다. 한편 브랜드 아이덴티티를 제품에 적극 반영하기 위해 현장소장 등을 대 상으로 매뉴얼을 제작 배포하고 교육시켜 아파 트 외벽에 무분별하게 도색된 래미안 심볼이나 기준 없이 작명된 단지명 등을 수정하는 등 다 양하고 적극적으로 전략적 브랜드 관리를 수행 하였다.

가격전략에 있어 소비자 정보에 기초한 최적 수용가격대의 도출에 주력하였다. 즉 고객이 지 불할 수 있는 가격과 회사가 취할 수 있는 가 격간의 격차를 최소화할 수 있도록 상황에 적 합한 최적수용가격대를 산출하였다. 이 가격 결 정을 위해 입지, 분양시기, 분양규모, 가업의 난 이도, 경쟁상화, 층/향별 분포를 종합적으로 고 려하고 래미안 브랜드의 부가가치를 포함한 미 래가치 분석에 의거해 종합 판단하였다. 
유통전략으로 런칭기부터 활성화되었던 주택 문화관을 모델하우스로서의 기본 기능 위에 문 화 이벤트 공간이자 다양한 마케팅의 공간으로 활용하고자 하였다. 또한 래미안의 새로운 라이 프스타일 체험을 통한 고객의 브랜드 로얄티 강화를 꾀하는 등 타겟 트렌드가 반영된 브랜 드 체험의 공간으로 활성화시켜 주택문화관을 명소화 하기 위한 노력을 경주하였다.

촉진전략은 브랜드 아이덴티티 재정립을 통 한 파워브랜드 구축의 목표를 달성함에 있어
가장 중요한 커뮤니케이션 수단이라 할 수 있 다. 이를 위해 래미안은 통합적 마케팅 커뮤니 케이션(IMC) 전략을 더욱 강력히 추진하여 매 체 특성에 따른 커뮤니케이션 목표에 따라 일 관되게 브랜드 컨셉을 전달하고자 하였다. 즉 불특정 다수를 대상으로 하는 TV 광고 외에도 세분화된 고객계층별로 가장 효율적인 매체를 적절히 활용하였다. TV 광고는 30-40대 주부 를 타겟으로 하여 연중 일정 물량을 지속형으 로 운영하되, 분양시점을 고려하여 신문, 잡지,

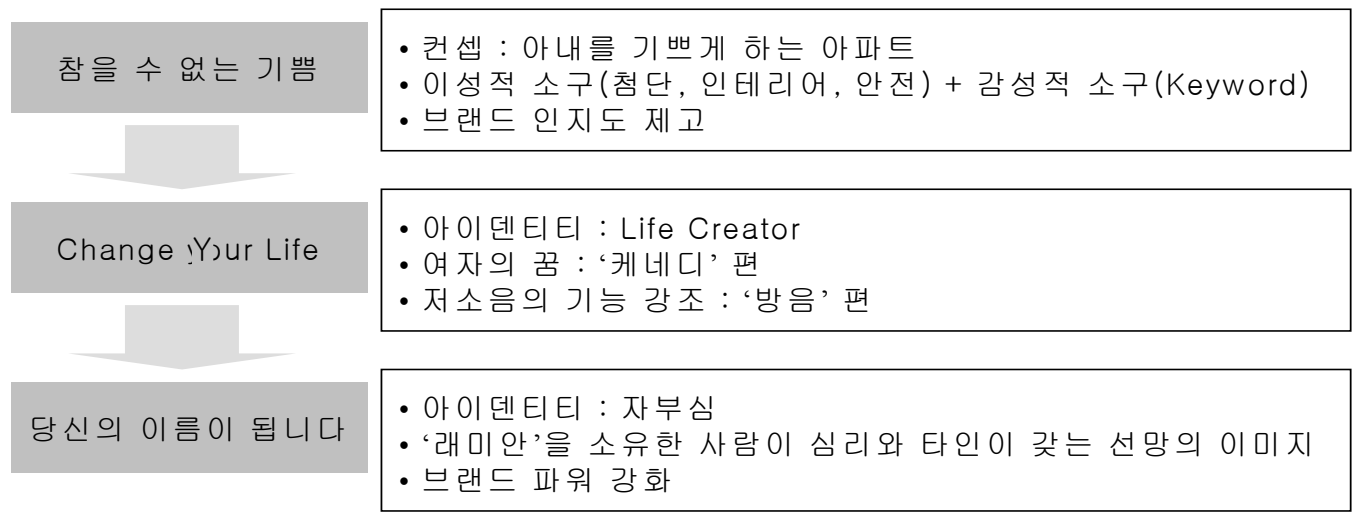

<그림 3-2> 브랜드 재도약을 위한 마케팅믹스 전략

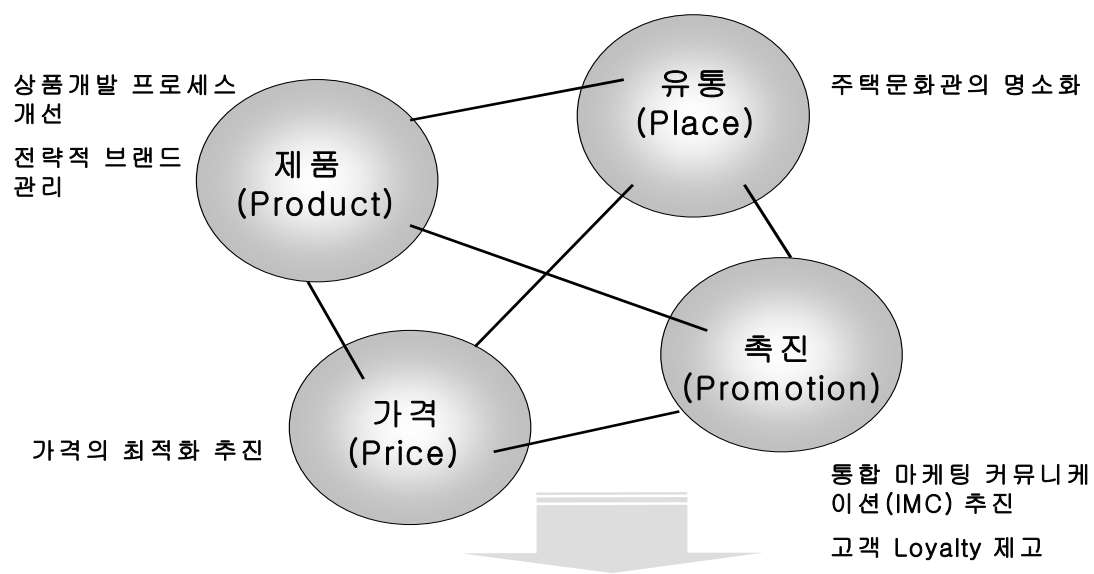

“리딩브랜드에서 파워브랜드로” 
인터넷 매체, 이벤트 등을 이용한 분양 광고를 효율적으로 실시하여 광고의 효율성을 제고하 였다. TV 광고에 있어 브랜드 컨셉인 '자부심 이 다른 아파트'를 소비자의 감성 언어로 표현 하기 위해 "당신의 이름이 됩니다"를 슬로건으 로 제정하고 다른 마케팅 커뮤니케이션 활동과 의 연계성을 검토하는 등의 면밀한 전략이 수 립되었다. 또한 다양한 대고객 행사를 통해 래 미안 스타일을 체험하는 기회를 제공하고 소비 자의 심리적 가치와 자부심을 강화시켜 브랜드 충성도를 제고하고자 하였다.

고객관리의 강화를 위해 $\mathrm{CRM}$ 시스템을 운영 하여 과거와는 다른 고객 개념을 정립하고자 하였다. 우선 고객세분화를 실시하여 고객과의
관계강화 차원에서 핵심타겟을 신규고객에서 기존고객으로 변화시키는 고객 재정의 작업을 실시하고, one-to-one의 관점에서 전략을 수행 하였다. 또한 40 만명의 고객 $\mathrm{DB}$ 구축과 함께 체계적인 고객관계관리 $(\mathrm{CRM})$ 체계를 도입하 고 우량고객과의 밀착 관리를 통해 회원고객의 가치를 높이고자 하였으며, 래미안 홈페이지도 다양하고 지속적인 이벤트 프로모션을 통해 래 미안 회원의 브랜드 충성도를 높이고 다양한 고객들의 각종 제안과 고객 욕구 변화를 점검 하는 안테나 샵 기능도 강화하였다.

이처럼 상호보완성과 일관성이라는 원칙아래 k 수립된 마케팅믹스 전략의 전개를 통해 '래미

<표 3-1> 연도별 주요 마케팅전략

\begin{tabular}{|c|c|c|}
\hline \multirow[b]{2}{*}{ 연도 } & \multicolumn{2}{|c|}{ 주요 마케팅 전략 } \\
\hline & 추진 계획 & 추진 결과 \\
\hline 2000년 & $\begin{array}{l}\text { - 상품차별화 } \\
\text { - 과학적인 브랜드 관리 } \\
\text { - 효과적인 홍보/광고 } \\
\text { - 관계마케팅 강화 } \\
\text { - 마케팅 역량 강화 및 조직운영 개선 }\end{array}$ & $\begin{array}{l}\text { - 브랜드 관리 시스템 기반 조성 } \\
\text { - 가격 결정의 과학화: 분양가 차등폭 확대 } \\
\text { - 고객 관계 경영 기반 구축 } \\
\text { - 공동마케팅 추진 }\end{array}$ \\
\hline 2001년 & $\begin{array}{l}\text { - 가격산정 능력 제고 } \\
\text { - Core Needs 중심의 상품차별화 } \\
\text { - 브랜드 가치 제고 } \\
\text { - One to One 커뮤니케이션 추진 } \\
\text { - 고객 관리 인프라 구축 }\end{array}$ & $\begin{array}{l}\text { - 리딩 브랜드로 도약 } \\
\text { - CRM 기반 구축 } \\
\text { - 고객 서비스 개선 } \\
\text { - 주택문화관 운영 개선 }\end{array}$ \\
\hline 2002년 & $\begin{array}{l}\text { - 전략적 브랜드 관리 } \\
\text { - 고객 로얄티 제고 } \\
\text { - 시장정보 수집 분석 및 가공의 과학화 } \\
\text { - 통합마케팅커뮤니케이션(IMC) 추진 } \\
\text { - 주택문화관 명소화 }\end{array}$ & $\begin{array}{l}\text { - 브랜드 플랫폼, 아이덴티티 체계 확립 } \\
\text { - 브랜드 자산 평가 및 관리 방안 수립 } \\
\text { - NCSI 5년 연속 } 1 \text { 위, K-BPI } 1 \text { 위 달성 }\end{array}$ \\
\hline 2003년 & $\begin{array}{l}\text { - 브랜드 관리 강화 } \\
\text { - 통합마케팅 커뮤니케이션 지속적 추진 } \\
\text { - 소비자 니즈파악을 통한 상품정교화 }\end{array}$ & $\begin{array}{l}\text { - NCSI 6년 연속 } 1 \text { 위, } \mathrm{K}-\mathrm{BPI} 1 \text { 위 달성 } \\
\text { - 중장기적 고객 관계 관리 토대 확립 } \\
\text { - CSI 모델 재구축 }\end{array}$ \\
\hline
\end{tabular}


안'의 브랜드 위상을 훼손시킬 수 있는 위험요 소를 최소화하고 이를 통해 브랜드 가치를 극 대화시킬 수 있었다.

브랜드 런칭이 이루어진 2000년부터 브랜드 재도약의 시기인 2003년까지의 연도별 주요 마케팅 전략을 요약하면 아래의 <표 3-1>과 같다.

\section{3 브랜드 마케팅의 성과}

삼성물산은 래미안 브랜드를 통하여 고객의 욕구를 충족시키고 경쟁력을 강화시킴으로써 기업가치를 상승시키는 것을 핵심전략으로 채 택하고 있다. 이에 따라 브랜드 마케팅 활동이 효과적으로 전개되어 있는가에 대한 정기적인

<그림 3-4> 브랜드 이미지 포지셔닝 맵

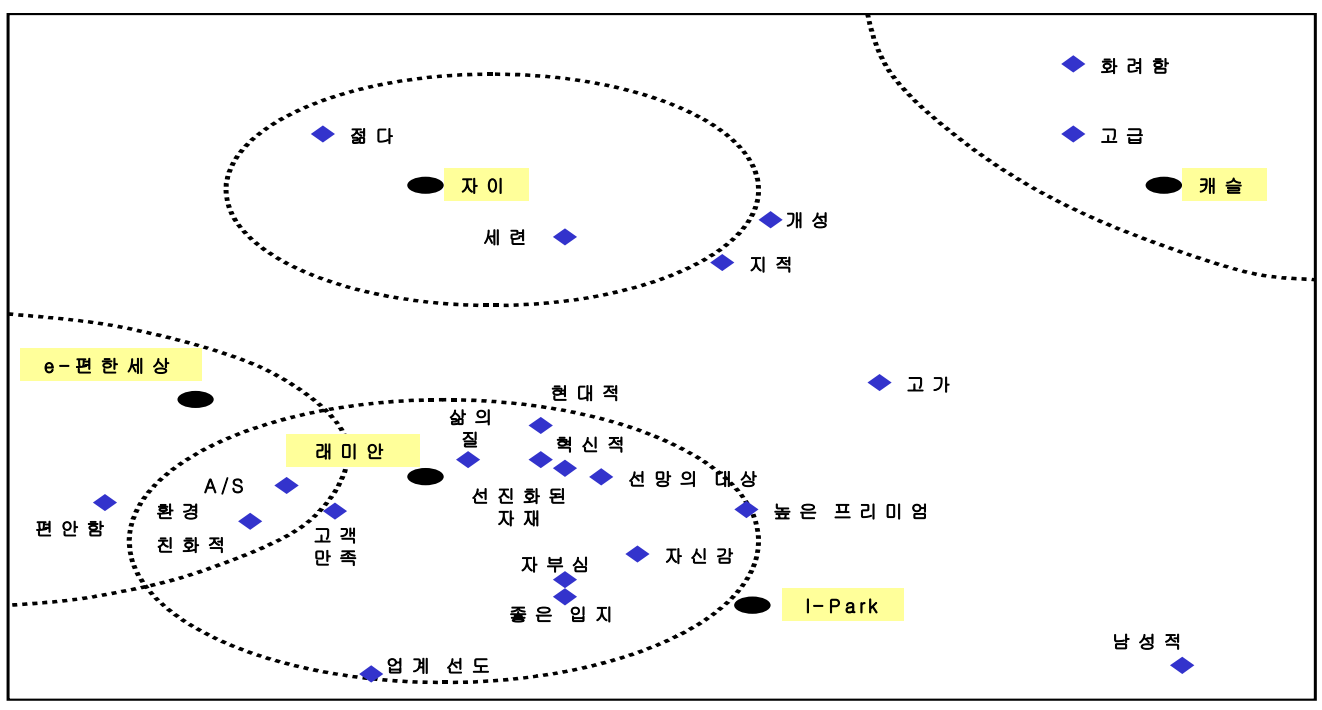

트렌드 창출을 통한 삼성물산 래미안의 브랜드 마케팅전략 135 
관리를 목적으로 2002년 5월 래미안 브랜드의 <그림 3-5> 래미안의 재무적 가치평가를 실시하였다. 이러한 가치 평가는 스 탠포드대 스리니바산 교수와 고려대 박찬수 교 수가 공동개발한 EQUITY MAP II를 이용하여 분석되었다. 그 결과 래미안의 브랜드 자산에 기인한 평당 가격 프리미엄은 475.5만원으로 이 는 응답자들이 동일한 상품이라 할지라도 브랜 드 구축 노력을 기울이지 않은 base brand에

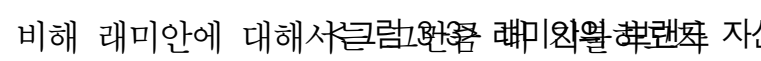
하나ㅇㅓㅓ을 의미한다. 이러한 평당 가격 프리미 엄을 $80^{\circ}$ 햐후 공급물량에 적용시 2002년뽁. 4 연간

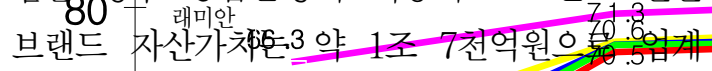

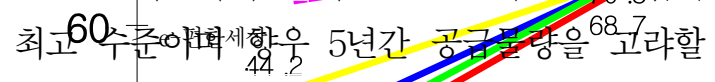

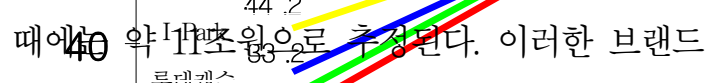

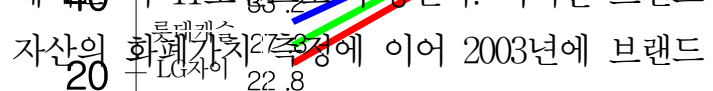
자산의 지수화 작업을 수행한 결과 래미안은 브랜브 차산 구성한및모닌 인지도, 품질,품찰랜드 이미지, 회사 이미지 모두에서 경쟁 브랜드 대

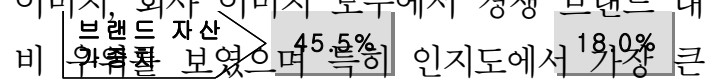
우위를 보이고 있는 것으로 나타났다.

또한 브랜드 이미지에 있어 래미안은 고가격, 프리미엄, 업계선도, $\mathrm{A} / \mathrm{S}$, 자부심, 선망의 대상 이라는 항목에서 상대적인 우위를 보이고 있어 브랜드 아이덴티티 정립과 이에 따른 브랜드 마케팅의 노력이 고객의 지각 속에 뚜렷이 각 인되어 있음을 알 수 있다.

브랜드 자산 가치를 객관적인 증명은 탁월한 경영실적의 향상에서도 볼 수 있다. <그림 3-5> 에서 보는 바와 같이 삼성물산은 '래미안' 출시 이후 재무적 성과를 포함한 경영지표의 개선이 괄목할 만큼 이루어졌음을 알 수 있다.

즉 '래미안'이 출시된 2000년을 기점으로 비교 해 볼 때 수주, 시공권 확보, 매출, 매출 이익

측면의 성과 지표가 대폭 상승했음을 알 수 있 다. 또한 폭발적인 청약경쟁률을 기록하여 2001 년 문정 33평형의 경우 705:1과 함께, 2002년

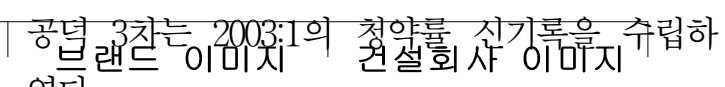
였다.

또한 $21 \frac{71}{\circ} \%$ 인력있는 대외기관드누두부터의 인증 및 수상이 잇따라 주어졌다. 괄목한 만한 것으 로 한국생산성본부와 조선일보, 미국미시간대학 이 공동으로 실시한 국가고객만족도(NCSI) 조 사에서 삼성물산의 래미안이 아파트 부문 7년 연속 1 위라는 대기록을 세웠다는 점을 들 수 있다. 국가고객만족도는 국내외에서 생산, 국내 최종소비자에게 판매되고 있는 제품 및 서비스 품질에 대해 해당 제품을 직접 사용해보고 이 제품과 관련된 서비스를 받아본 고객이 직접 평가한 만족수준의 정도를 측정 및 계량화한 지표를 의미하는 것으로, 시장 점유율을 측정하 기 힘든 아파트 부문에서 매우 중요한 척도로 사용되고 있다. 특히 국가고객만족도 조사는 230여 개 기업을 대상으로 해마다 실시되고 있 
<표 3-2> 최근 7년간 NCSI 점수 비교

\begin{tabular}{|c|c|c|c|c|c|c|c|}
\hline 구분 & 1998년 & 1999년 & 2000년 & 2001년 & 2002년 & 2003년 & 2004년 \\
\hline \hline 삼성물산 & 65 & 68 & 71 & 70 & 70 & 73 & 76 \\
\hline 대림산업 & 61 & 63 & 57 & 56 & 64 & 64 & 75 \\
\hline 현대 & 53 & 57 & 59 & 66 & 63 & 66 & 74 \\
\hline 현대산업 & 53 & 56 & 60 & 65 & 63 & 65 & 70 \\
\hline
\end{tabular}

는데, 이중 7 년 연속 1위는 삼성전자(휴대전화 트렌드를 창출하고 주도한 대표적인 아파트 브 기 부문)와 소니코리아(컬러TV 부문) 등 손꼽 랜드이다. 래미안이 후발주자의 약점을 극복하 을 정도다.

또한 한국능률협회가 선정하는 한국 산업의 브랜드 파워 $(\mathrm{K}-\mathrm{BPI})$ 에서도 래미안이 3 년 연 속 1위를 차지하였다 $<$ 그림 3-6>의 연도별 그 래프 중 누락분은 해당 년도 조사대상이 아님 을 의미). 고 단기간내에 리딩 브랜드로서의 위상을 정립 하고 뛰어난 경영성과를 이룰 수 있었던 주요 성공요인은 다음의 몇가지로 축약시킬 수 있다.

첫째, 브랜드 자산 창출을 최대화하기 위해 브랜드 자체가 마케팅 프로그램에 효과적으로 통합될 수 있도록 최적의 마케팅믹스 전략을 설계하고 추진하였다. 즉 브랜드 아이덴티티 체

<그림 3-6> 업체별 K-BPI 점수 비교

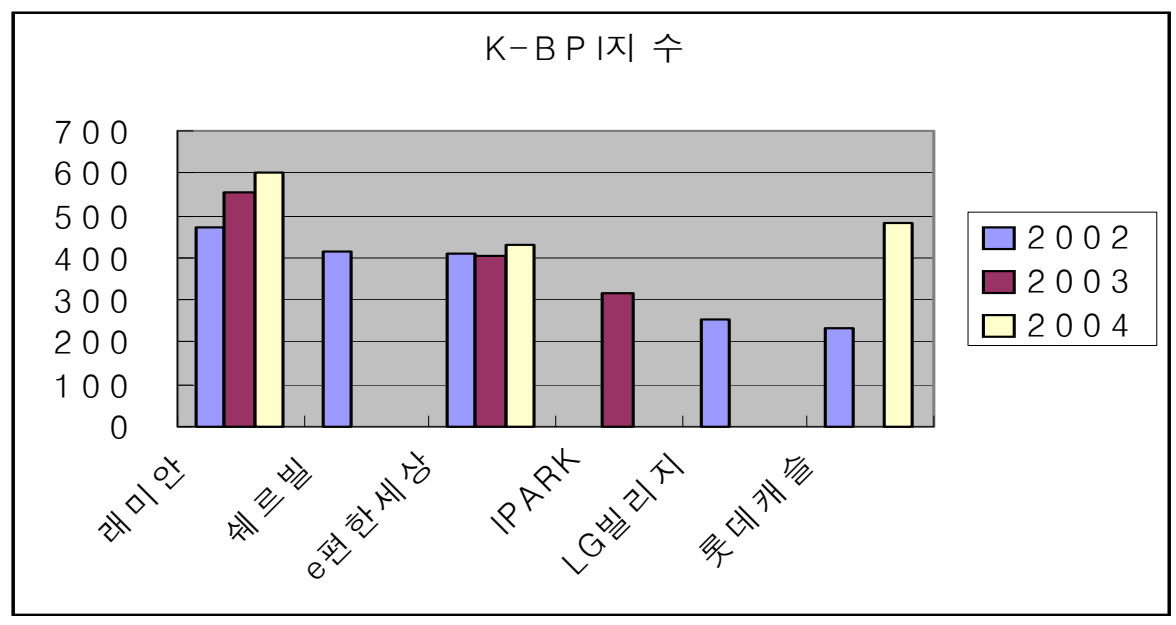

IV. 래미안의 주요 성공요인

삼성물산 래미안은 브랜드의 개념조차 생소 한 건설업계에서 브랜드 마케팅의 새로운 전략
계를 구축하는 데에 그치지 않고 이를 소비자 에게 효과적으로 전달하기 위하여 일관성있고 체계적으로 전사적인 브랜드 마케팅 노력을 경 주하였다. 또한 브랜드 가치 제고를 위한 마케 
팅 전략 수립에 있어 브랜드 마케팅 활동에 대 한 브랜드 자산 평가를 포함한 지속적인 모니 터링과 피드백을 실시하고 그 결과를 반영하며, 필요한 경우 마케팅 프로그램의 수정도 과감히 단행하였다. 이는 곧 주택건설 업계 최초의 '전 략적 브랜드 관리'의 시스템 정착을 위한 노력 으로 볼 수 있다.

둘째, 래미안을 중심으로 내부 역량을 집중하 여 전사적인 차원에서 수주, 분양으로부터 판매 후 서비스에 이르기까지 여러 단계에 걸쳐 분 산되어 있는 조직의 역량을 브랜드 중심으로 결집시키기 위해 타 부서와의 끈질긴 논의 과 정을 거쳐 전사적인 브랜드 마케팅의 토대를 마련하였다는 점이다. 브랜드 마케팅을 주도하 는 마케팅팀 역시 기획, 광고/브랜드 관리, 조 사, $\mathrm{CRM}$ 의 각 파트 업무계획을 수립하고 실행 함에 있어 래미안의 브랜드 컨셉에 적합한 전 략적 범위 내에서 운용될 수 있도록 기반을 조 성하는 데에 진력하였다.

셋째, 전략적 사고 및 마케팅 실행의 전반에 걸쳐 outside-in 접근방식을 채택하였다는 점이 다. 과거 주택건설 시장의 공급자 중심 사고 즉 inside-out 접근방식에서 벗어나, 래미안이라는 차별적 가치를 지닌 강력한 브랜드의 존재를 고객에게 포지셔닝시키기 위해 철저한 수요자 중심의 접근을 시도하였다. 이는 곧 상품개발과 입지선정으로부터 분양에 이르기까지 고객의 욕구 및 가치의 충족시켜 줄 방안을 철저히 분 석하여 그 결과를 적극 반영하였다. 또한 다양 한 고객과 전문가 집단의 참여를 제도적으로 확립하여 고객지향적 상품개발 및 품질관리에 일조하도록 하였다.

넷째, 래미안이 업계 최고의 리딩 브랜드이자
장기적인 자산 가치를 지닌 파워브랜드로 성장 함에 있어 강력한 동인으로 작용할 수 있었던 것으로 통합적 마케팅 커뮤니케이션(IMC)의 실행을 들 수 있다. 즉 커뮤니케이션 목표에 따 라 다양한 매체의 특성을 고려하되 이들 매체 간 효율성을 극대화할 수 있도록 IMC 전략을 수립하고 실행하였다. 특히 TV 광고를 위시한 방송광고를 통하여 명확히 설정(single concept) 된 브랜드 컨셉을 전달하여 브랜드 이미지를 제고하는 한편, 분양 등 구매촉진을 위해 인쇄 광고와 직접마케팅 관련 매체를 운용하였다. 이 와 아울러 다양한 대고객 이벤트를 주택문화관 과 홈페이지를 중심으로 하되 $\mathrm{TPO}$ 에 구애받지 않는 상황마케팅과 체험마케팅을 추진하여 장 단기적인 판매 및 커뮤니케이션 성과를 이룰 수 있었다.

다섯째, 주택업계에서 생소한 차별화된 고객 관리를 통해 고객충성도 제고와 강력한 브랜드 자산 구축을 이루었다는 점이다. 그 일환으로 주택업계 최초의 주택전문 홈페이지와 $\mathrm{DB}$ 회원 40만명의 $\mathrm{CRM}$ 시스템을 도입하면서 불특정다 수를 대상으로 하는 mass 마케팅에서 벗어나 세분화된 고객별로 가장 적합한 차등화된 정보 와 서비스를 제공하는 one-to-one 마케팅 체제 를 구축하여 전략적 고객관리의 기반을 확보하 였다.

여섯째, 끊임없는 제품혁신 활동과 품질향상 노력으로 보다 앞선 제품차별화 전략으로 고객 의 지각품질을 포함한 고객만족도를 제고시켰 다. 이를 위해 국내최초로 8개 품질별로 주거성 능지표를 개발해 소비자 선택기준으로 제시하 는 한편, 사이버 디지털 홈네트워크 시스템 위 주의 인텔리전트 모델을 개발하여 선별적으로 
적용하는 등 미래 효용가치를 극대화시키기 위 한 노력의 결과, 그 성과가 가시적으로 나타나 고 있다.

\section{$\mathrm{V}$. 래미안의 향후 전략적 과제}

앞서 살펴본 바와 같이 삼성물산은 국내 최 초로 아파트 시장에서 래미안을 통해 브랜드 마케팅을 본격적으로 도입하여 리딩브랜드 입 지 구축과 함께 괄목할 만한 경영성과를 단기 간에 이룰 수 있었다. 이러한 위상과 함께 주택 업계 최고의 파워 브랜드로 장기적인 성공을 이루기 위해 향후 고려해야 할 전략적 과제를 검토하면 다음과 같다.

첫째, 경쟁상황을 포함한 주요 환경의 변화에 따라 기존 전략의 전향적인 재검토가 필요할 것이다. 삼성물산에 의해 최초로 전개된 브랜드 마케팅은 이제 아파트를 위시한 주택건설업계 에서 더 이상의 차별적인 전략이라고 보기 어 려울 정도로 업계마다 제각기 브랜드 마케팅을 시행하고 있으며 전략 또한 점차 독자성을 확 보하기 힘들어진다. 이는 국가고객만족도를 포 함한 소비자 지표에 있어 경쟁브랜드간의 격차 가 줄어든 현상에서도 볼 수 있다. 그러므로 래 미안이 브랜드 마케팅에 있어서의 선점 우위 (pioneering advantage)를 더 이상 기대하기는 어렵다. 또한 주택유형의 다각화 추세와 이에 따른 시장세분화의 급속한 진전으로 주택환경 의 변화를 선도하는 사업추진의 방향성 검토가 선행되어야 할 것으로 보인다. 이에 따라 장기 적 성장관점에서 볼 때 래미안의 지속적인 대 표브랜드화 여부를 포함한 브랜드 마케팅 전반
에 대한 재검토가 필요한 실정이다.

둘째, 전략적 브랜드 관리가 지속적으로 필요 하다. 래미안의 주요 성공요인인 체계적 브랜드 관리는 아파트 브랜드의 보편화, 기분양된 래미 안 아파트 단지의 연령화, 주택유형의 다양화에 따른 사업다각화 및 multi-brand화 등으로 인 해 그 정체성과 일관성에 대한 관리가 점차 힘 들어질 수 있다. 현재에도 브랜드 매뉴얼 지침 과는 다른 네이밍 체계의 혼용의 우려가 있으 며, 여전히 삼성과 래미안의 결합여부에 대해 논란의 여지가 있다. 이에 대한 명확한 지침 적 용 및 전략적 재검토와 함께 향후 브랜드 포트 폴리오 전략의 수립에 대한 적극적 논의가 필 요하다고 본다.

셋째, 래미안의 핵심 아이덴티티인 '자부심'을 포함하여 브랜드 아이덴티티 체계의 재검토가 필요하다. 브랜드 자산의 원천인 인지도, 속성 지각, 비속성 지각 중 브랜드 이미지에 해당하 는 비속성 지각은 경쟁자들이 내세우는 브랜드 컨셉인 고급화, 편리함, 아름다움, 안전함, 자부 심 등과 크게 다르지 않아 래미안만의 브랜드 이미지가 보편화될 위기에 있다. 그러므로 현재 의 아이덴티티 체계를 비교 분석하여 필요할 경우 아이덴티티 리노베이션을 과감히 도입하 는 것도 고려해 볼 만 하다.

넷째, 차별화된 마케팅 역량의 강화가 내부적 으로 필요하다. 브랜드가 아파트 선택 기준으로 그 중요성이 당분간 지속될 것으로 보이나, 최 근 아파트 브랜드의 경쟁상황으로 볼 때 브랜 드 자체로서는 크게 차별화되지 못하는 성숙단 계에 접어들고 있다. 그러므로 브랜드 인지도나 이미지를 높이기 위한 통상적인 마케팅 활동의 수준에서 탈피해야 한다. 그러므로 마케팅 조직 
은 소비자에 대한 깊은 이해를 바탕으로 브랜 드의 차별화된 포지셔닝을 구축하고 이를 제품 과 서비스에 잘 연계될 수 있도록 촉진자의 역 할을 수행해야 한다. 또한 웰빙, 환경, 리모델 링, 유비쿼터스 등 새로 부각되고 있는 고객 니 즈를 추적하고 소비자의 만족도를 주기적으로 조사하여 기획, 설계, 시공 등 프로세스별 피드 백을 더욱 강화하기 위해 조직 역량을 강화하 는 한편 보다 신속한 의사결정체계를 갖추어야 할 것이다.

다섯째, 마케팅 커뮤니케이션 효과를 제고시 키기 위한 광고캠페인 전략의 개선이 요청된다. 브랜드 이미지를 형성함에 있어 주요한 역할을 담당하고 있는 광고 캠페인에 대해 높은 관심 을 보이고 있는 현실로 볼 때, 경쟁 브랜드 대 비 래미안 광고는 임팩트나 컨셉 소구에 있어 개선의 여지를 여전히 안고 있다. 기존 래미안 의 광고 캠페인은 지속적으로 학습된 연상 체
계의 매개체가 불충분하다고 볼 수 있으며 이 는 캠페인의 체계적 연속성 부족에 기인한다고 볼 수 있다. 또한 대체적으로 정적이며 시각적 측면이 강조되어 주목성과 공감성이 상대적으 로 낮다. 그리고 빅모델의 운용과 소구컨셉의 제시 등 메시지 전략의 효율성 제고 방안에 대 해 체계적인 검토가 필요할 것이다.

<사례 접수일: 2004. 9. 14> <게재 확정일: 2004. 10. 13> 


\title{
Making Trend-Based on Brand Marketing Strategy of Samsung Raemian
}

\author{
Jung Ok Jeon* \\ Bong Jin Cho** \\ Myung Sik Lee***
}

\begin{abstract}
As a pioneering company who entered new era of brand marketing in the domestic housing development market, Construction Division of Samsung Corporation achieved enormous business performance with the brand asset at the short time period. For the great success, they tried to apply customer's value into marketing mix strategy thoroughly, and created new trend of brand marketing strategy in the field. This case deals with the Samsung Corporation's efforts mainly focused on Raemian's brand marketing strategy to build the best powerful brand, and shows which are the key success factors, and suggest strategic implications to succeed in the long run.
\end{abstract}

Key words: Samsung Raemian, brand marketing, brand asset, housing development.

* Professor, Div. of Business Administration, Pukyong National University.

** Professor, Dept. of Business Administration, Keimyung University.

*** Professor, Div. of Business Administration, Sangmyung University. 